\title{
Recombinant protein detection and its content in total protein, lipids and toxic antinutritional substances in Mexican maize
}

\author{
Peña Betancourt Silvia Denise ${ }^{1^{*}}$, Posadas Manzano Eduardo², \\ Valladares Carranza Benjamín ${ }^{3}$ \\ ${ }^{1}$ Laboratorio de Toxicología, Departamento de Producción Agrícola y Animal, UAM-Xochimilco, México, D.F., Mexico; \\ *Corresponding Author: silvia_dpb@hotmail.com \\ ${ }^{2}$ Departamento de Rumiantes, Facultad de Medicina Veterinaria y Zootecnia UNAM, México, D.F., Mexico \\ ${ }^{3}$ Centro de Investigación y Estudios avanzados en salud animal, FMVZ-UAEM, México
}

Received 18 July 2013; revised 19 August 2013; accepted 15 September 2013

Copyright (C) 2013 Peña Betancourt Silvia Denise et al. This is an open access article distributed under the Creative Commons Attribution License, which permits unrestricted use, distribution, and reproduction in any medium, provided the original work is properly cited.

\section{ABSTRACT}

The engineering genetic technology has developed Bt maize events which contain recombinant protein that will be safe for the consumer. The aflatoxins are contaminants present in maize capable of producing cancer and decreasing the immune response in human, additionally contained polyphenols compounds considered non nutritive. The objective of this study was to identify the presence of recombinant protein in hybrid and local varieties of corn and evaluate the content of aflatoxins and tannins. 25 samples of white grain maize for human consumption were collected, 12 were for hybrid maize and 13 local varieties, from the states of Hidalgo, Mexico and Morelos. Samples were analyzed for Cry1Ab/Cry1Ac, using lateral flow strip method, crude protein and lipids by standard methods. Aflatoxins were assessed by comercial Elisa kit and tannins by spectroscopy method. The data were grouped in a completely random model and an analysis of variance was performed. The results indicated that $44.5 \%$ of hybrid corn was positive by Bt-Cry1Ab/1Ac proteins, containing $9.02 \% \pm 2.5$ lipids and $11.33 \% \pm$ 2.2 crude protein, $189 \pm 0.92 \mathrm{mg} / \mathrm{g}$ of tannins and $6.36 \pm 3.3 \mu \mathrm{g} \cdot \mathrm{g}^{-1}$ aflatoxins. The local maize samples $(55.5 \%)$ were negative to $\mathrm{Bt}-\mathrm{Cry} 1 \mathrm{Ab} /$ Cry1Ac, which protein content was of $8.68 \% \pm$ $0.90,6.14 \%$ lipids $\pm 2.3,273 \pm 0.40 \mathrm{mg} / 100 \mathrm{~g}$ tannin and $7.15 \pm 3.3 \mu \mathrm{g} \cdot \mathrm{g}^{-1}$ of aflatoxins. In conclusion, we observed an improvement of nutri- ent composition in hybrid maize with Bt proteins, and decrease in tannins content comparing with some local varieties without $\mathrm{Bt}$ proteins. The effectiveness of $\mathrm{Bt}$ maize expressing the Cry1 $\mathrm{Ab} /$ Cry1 Ac in reducing aflatoxin contamination was not observed, therefore, additive affects of aflatoxins contamination in maize Bt-Cry need to be further investigated in cancer disease development.

Keywords: Transgenic Maize; Mycotoxins; Safety; Toxicants; Anti-Nutritional Protein

\section{INTRODUCTION}

Recombinant DNA technology has been running for over 30 years in various agricultural crops worldwide [1]. Corn is a staple in the food and feed because of its high energy content and low cost. The genetically modified maize events have a higher protection against insects and the herbicide glyphosate, due to the inclusion of genes from bacterias such as Bacillus thuringiensis, Escherichia coli and some species of Agrobacterium. The cry genes express proteins with toxic action on mainly Lepidoptera insects [2,3]. The events of Bt-176, MON-810 and Bt-11, contain one or more genes (Cry1 Ab, CP4 and esps) expressing Cry1 A proteins, Cry1 Ac, Cry2Ab. Bt events have many advantages over isogenic counterpart (non Bt maize), such as an increase in lysine amino acid, enhanced ability to prevent fungal pathogens [4], and their toxins [5], between others, however, not enough evidence is currently available in Mexico to support or refuse the safety of proteins Cry present in Bt maize $[6,7]$. 
The introduction of Bt corn seed in Mexico has generated a considerable debate in public due to ignorance of its implications for human health, principally in the develop of allergy diseases [8,9]. In the literature it exists information about the toxicity principally made with laboratory animals in which they have been probed a very low acute oral toxicity $[10,11]$, on the other hand substantial equivalence studies have failed to show differences from isogenic corn (non Bt maize), other works have shown resistant to fungal contamination of genus Fusarium verticillioides and Aspergillus flavus, both found in the mycoflora present in maize produced under high temperatures and humidity, climatic conditions in states of Mexico, such as Hidalgo, Mexico and Morelos [12]. The aflatoxins produced by Aspergillus flavus, filamentous fungi, causes a decrease in immune function and tumor formation in the liver. Fusarium verticillioides synthesize fumonisins, and can lead to esophageal cancer [13]. The antinutritional substances which comprise tannins, a group of polyphenols, present in small corn concentrations, are known for its role as natural protective agents against pathogenic microorganisms during plant growth in the field, and by the capacity to precipitate proteins and starch which causes a decrease in the crop nutritional value [14]; the gallic acid is involved in a lymphocytes Th1 inhibition, then interleukine IL-1b secretion, and cyclooxygenase- 2 gene expression. Also it is important to remember that epigenetic modifications in DNA play a role in tumorigenesis [15], like to emphasize the studies in which rats were fed with Bt maize (MON810) for 30 and 90 days. It was observed a decrease in $\mathrm{T}$ and B cells specific for CD4 and CD8 sub-populations in the treated rats, which shows a decrease in lymphocytes Th1 and interleukine response [16].

The protein products of the expression of a transgene can be determined using immunological methods, like strip test (strips-reactive), which may have a nitrocellulose support for a specific antibody conjugated to a target protein staining reagent. The result is qualitative (positive or negative) and the detection limit is between 0.5 and $2 \%$ for corn events MON810 and Bt11 which are protected from insects by the crylAb gene from Bacillus Thuringiensis.

The aim of this study was to identify the presence of Bt-Cry1 Ab protein/Cry1Ac in 25 commercial corn samples from the center of Mexico and to compare among nine pairs about the protein content, lipid, aflatoxins and tannins.

\section{MATERIAL AND METHODS}

\subsection{Materials}

\section{Grain Collect}

There were two visits INIFAP Experimental Fields in the states of Hidalgo and Morelos. The State of Mexico samples were provided by the FES-Cuautitlán, UNAM. A total of 25 accessions of white grain maize, identified commercially as P30G40, P30V46, P30T26, panther, leopard, bear, bengala, puma 1167, puma 1085, H-155, H-159, H-515, H-519, H-516, DK-2027, DK-2060, cronos, aspros, V5370, toluqueño, bola, chalco, puebla, tlaxcala, añejo and chapingo. All samples were milled into whole grain flour passed through $250 \mu \mathrm{m}$ screen mesh, prior their analyses.

\subsection{Methods}

\subsubsection{Physical Characterization}

It was determined moisture content of each sample grain by duplicate according to standard method $[17,18]$.

\subsubsection{Chemical Analysis}

The content was determined by the crude protein MacroKjeldahl method and the fat by the Goldfish method 7044 [19], performing every duplicate analysis. The identification of Cry1Ab-1Ac was assay by lateral flow strip method (ImmunoStrip test) of Agdia laboratories, USA.

\subsubsection{Aflatoxins Analysis}

Aflatoxin analysis was performed by enzyme immunoassay ELISA (Aflatoxin Ridascreen kit from R-Biopharm AG Germany) to cereals. The assay detection limit is $2 \mathrm{mg} \cdot \mathrm{kg}$. It was prepared by $5 \mathrm{~g}$ ground corn flour finely and the extraction was performed with $10 \mathrm{~mL}$ of the methanol: water $(50: 50 \mathrm{v} / \mathrm{v})$, according to the manufacturer's procedure, the absorbance was read at $650 \mathrm{~nm}$ on a plate reader and the data was passed to EXE RIDAWIN Software multiplying by the dilution factor generating results in $\mu \mathrm{g} \cdot \mathrm{g}^{-1}$.

\subsubsection{Poliphenols Compounds Analysis}

The extraction of free phenolic compounds was performed according to Dewanto et al., (2002): $5 \mathrm{~g}$ of ground whole grain was blended with aqueous methanol (80:20, v/v), for 15 minutes, using achilled waring blender. The absorbance readings at $725 \mathrm{~nm}$ were taken in spectrophotometer UV-visible light, for quantification. Total phenolic content was expressed as mg tannic acid/ $100 \mathrm{~g}$, based on a standard curve of $0-500 \mu \mathrm{g}$ de tannic $\mathrm{acid} / \mathrm{mL}$.

\subsubsection{Bt-Cry1Ab/1Ac Protein Detection}

Corn kernels were ground into a fine powder and the extraction was performed with double-distilled water, placing it in a beaker and placed the strip immune (ImmunoStrip Bt-Cry1Ab/1Ac Test, Agdia Laboratory, USA). 


\subsubsection{Statistical Analysis}

It was made an analysis of variance to determine differences between means in a completely randomized design.

\section{RESULTS}

From the total of the samples collected, only eighteen could be evaluated due to the loss of the material and insufficient quantity for four chemical analysis. The $44.5 \%$ of the samples were positive for Bt-Cry1Ab/1Ac protein. From twelve maize hybrids analyzed, all were white grain by human consumption, most of them $(33.33 \%)$ from Hidalgo State, $(22.2 \%)$ from Mexico State, and (11.11\%) Morelos, in all of them were detected qualitatively Bt-Cry1Ab/CrylAc proteins, and none of local varieties studied. The results showed that crude protein content in corn hybrids positive to BtCry1Ab/Cry1Ac was significantly higher that the composite in corn non Bt-Cry proteins $(11.33 \%$ versus $8.68 \%)$; as well as humidity (12.27 \% and $10.75 \%)$. The mean lipid content was significantly $(p \leq 0.05)$ higher (9.02\% compared to $6.14 \%$ ) (Table 1). Aflatoxins were identified in all samples analyzed in an average level of $6.75 \mu \mathrm{g} \cdot \mathrm{g}^{-1}$, a range to $2.0-13.0 \mu \mathrm{g} \cdot \mathrm{g}^{-1}$; in maize hybrids positive to Cry1 Ab/Cry1Ac proteins showed an average content of $6.36 \pm 3.3 \mu \mathrm{g} \cdot \mathrm{g}^{-1}$ compared to $7.15 \pm 3.3$ $\mu \mathrm{g} \cdot \mathrm{g}^{-1}$ non Bt-Cry protein, with any significant difference. The ranges of total phenolic levels observed among the 18 Mexican maize studied were 140 - $360 \mathrm{mg} / 100 \mathrm{~g}$ of grain flour. Among the group of maize with Cry proteins was $130-300 \mathrm{mg} / 100 \mathrm{~g}$ and a median to $189 \pm 0.92$ $\mathrm{mg} / 100 \mathrm{~g}$, and for the group of maize without Cry proteins was $200-360 \mathrm{mg} / 100 \mathrm{~g}$, with a median of $273 \pm$ $0.40 \mathrm{mg} / 100 \mathrm{~g}$, highlighting the hybrids 30T26, H-515, H-519 and Cronos by contented the greatest phenolic levels $(250$ - $270 \mathrm{mg} / 100 \mathrm{~g})$, however their content was slightly lower than levels founded in local varieties (300 - $360 \mathrm{mg} / 100 \mathrm{~g}$ ) (Table 2).

\section{DISCUSSION}

The protein $1 \mathrm{Ab} / 1 \mathrm{Ac}$ which was observed with immunological strips was quickly and effective, which agrees with the views expressed previously [20,21]. This finding, should alert epidemiologists as the food allergy due to importance in health, like, in Mexico, the allergy diseases increased in the last 40 years by effects of pollution, in others countries has been reported a prevalence of food allergy in $3.52 \%$, with the $9 \%$ due to allergens in vegetables, more than eggs or milk [22]. Moreover this study emphasizes the increase risk of food allergy in well-developed countries; it has been mentioned that food allergies are increasing due to physico-chemical modifications of food proteins and the development of
Table 1. Chemical analysis and identification of proteins Cry $1 \mathrm{Ab} / 1 \mathrm{Ac}$ in 18 commercial corn samples from the states of Hidalgo, Morelos and Mexico.

\begin{tabular}{ccccc}
\hline & $\begin{array}{c}\text { No. of } \\
\text { samples }\end{array}$ & $\begin{array}{c}\text { Moisture } \\
(\%)\end{array}$ & $\begin{array}{c}\text { Lipids } \\
(\%)\end{array}$ & $\begin{array}{c}\text { Proteins } \\
(\%)\end{array}$ \\
\hline $\begin{array}{c}\text { Local and hybrid } \\
\text { Corn negative hybrid } \\
\text { Cry protein 1Ab/1Ac }\end{array}$ & 10 & $10.75 \pm 0.58$ & $6.14 \pm 2.3$ & $8.68 \pm 0.86$ \\
$\begin{array}{c}\text { Hybrid Corn positive } \\
\text { hybrid Cry protein } \\
\text { 1Ab/1Ac }\end{array}$ & 8 & $12.27 \pm 0.89$ & $9.02 \pm 2.5$ & $11.33 \pm 2.19$ \\
\hline
\end{tabular}

Table 2. Aflatoxins and tannins content in different corn strains and varieties.

\begin{tabular}{ccc}
\hline Maize varieties name & $\begin{array}{c}\text { Aflatoxin B1 } \\
\left(\boldsymbol{\mu g} \cdot \mathbf{g}^{-1}\right)\end{array}$ & $\begin{array}{c}\text { Tannins } \\
(\mathbf{m g} / \mathbf{1 0 0} \mathbf{g})\end{array}$ \\
\hline $\begin{array}{c}\text { Local and hybrid Corn negative } \\
\text { hybrid Cry protein 1Ab/1Ac }\end{array}$ & $7.15 \pm 3.3$ & $273 \pm 0.40$ \\
$\begin{array}{c}\text { Hybrid Corn positive hybrid Cry } \\
\text { protein 1Ab/1Ac }\end{array}$ & $6.36 \pm 3.3$ & $189 \pm 0.92$ \\
\hline
\end{tabular}

new food processing agro-technologies, considering the emergence of new allergens [23]. Furthermore the results suggest that $\mathrm{Bt}$ maize hybrids have been commercially introduced to the country, which is because of importations and the need to increase the human grain consumption, it helps lower the risk of cardiovascular disease, type II diabetes and gastrointestinal cancer [24].

In general, the content view of humidity in all maize samples was appropriate because the law allows up to $15 \%$ for marketing. The higher content of protein and lipids in maize with recombinant protein (Bt-Cry1 Ab/ 1Ac), suggests a benefit due to hybridization and transgenesis, which is similar to the previously published, however it is necessary to consider that increased lipids in maize can promote the formation of reactive species (ROS), and subsequent liver damage, including cancer in humans [25].

The aflatoxin levels observed in all samples contained less than $20 \mu \mathrm{g}$ AFB1 $\mathrm{kg}$, so they are within allowed by Mexican legislation in corn for human consumption, but it is important to consider their genotoxic and carcinogenic effect and their chronic exposition, it can lead to DNA epigenetic modification, then in cancer disease, by the ingestion of low levels aflatoxins [26]. Additionally we did not found a significant reduction of aflatoxins accumulation as has been mentioned earlier [27,28], these differences may be caused by the influence of climatic conditions in the places of maize source and by different forms of production. The ranges of tannins levels founding in the 18 Mexican maize were lower than those reported previously [29], nevertheless confirms that most of the phenolic compounds present in bound form, not to mention the environmental effects on me- 
tabolism vegetal.

\section{CONCLUSIONS}

The result of this research indicates differences among hybrid and local maize commercialized in three states of Mexico about the presence of recombinant protein (BtCry1Ab/Cry1Ac).

The effectiveness of Bt maize expressing the Cry $1 \mathrm{Ab} /$ Cry1Ac in reducing aflatoxin contamination was not observed under climatic conditions of three states of Mexico, therefore, the additive effects of aflatoxins contamination in maize Bt-Cry need to be further investigated in cancer disease development.

We observed an improvement of nutrient composition in hybrid maize with Bt proteins, and a decrease in tannins content in comparison with some local varieties.

The immunological test strips for the identification of proteins Bt-Cry1Ab/Cry1Ac are efficient and fast.

\section{REFERENCES}

[1] James, C. (2004) Executive summary: Global status of commercialized biotech/GM crops. ISAAA Briefs No. 32 . ISAAA, Ithaca.

[2] Betz, F.S., Hammond, B.G. and Fuchs, R.L. (2000) Safety and advantages of Bacillus thuringiensis-protected plants to control insect pests. Regulatory Toxicology and Pharmacology, 32, 156-173.

http://dx.doi.org/10.1006/rtph.2000.1426

[3] Boisvert, M. and Boisvert, J. (2000) Effects of Bacillus thuringiensis var. israelensis on target and non target organisms. A review of laboratory and field experiments. Biocontrol Science and Technology, 10, 517-561. http://dx.doi.org/10.1080/095831500750016361

[4] Sevenier, R.M., van der Meer, I., Bino, R. and Koops, A.J. (2002) Increased production of nutriments by genetically engineered crops. Journal of the American College of $\mathrm{Nu}$ trition, 21, 199S-204S.

http://dx.doi.org/10.1080/07315724.2002.10719266

[5] Rubens, O.N. (2009) Calidad de los análisis de riesgo e inseguridad de los transgénicos para la salud ambiental y humana. La Revista Peruana de Medicina Experimental y Salud Pública, 26, 74-82.

[6] Traavik, T and Heinemann, J. (2007) Genetic engineering and omitted health research: Still no answers to ageing questions. Third World Network, Penang.

[7] Hails, H. and Kindererer, G. (2003) The GM public debate: Context and communication strategies. Nature Reviews in Genetics, 4, 819-826. http://dx.doi.org/10.1038/nrg1182

[8] Rance, F. Allergie alimentaire a $l^{\prime}$ arachide et aux fruits a coque. Allergologie Pedriatic, Paris.

[9] López, M.L.X., Oliart, R. and Valerio, A.G. (2009) Antioxidant activity, phenolic compounds and anthocyanins content of eighteen strains of Mexican maize. Food Science and Technology, 42, 1187-1192.
[10] Grisolic, C.K., Olibeira, F. E.C., Ramos, F.R., Lopes, M.C., Muniz, F.D.H. and Monnerat, R.G. (2009) Acute toxicity and citotoxicity of Bacillus thuringiensis and $\mathrm{Ba}$ cillus saphcericus strains in fish and mouse bone narrow. Ecotoxicology, 18, 22-26. http://dx.doi.org/10.1007/s10646-008-0252-7

[11] Peterson, G, Cunningham, S., Deutsch, L., Erickso, J., Quinla, A. and Raez, L.E. (2000) The risk and benefits of genetically modified crops: a multidisciplinary perspective. Conservation Ecology, 4, 13-18.

[12] Chassy, B.M. (2002) Food safety evaluation of crops produced through biotechnology. Journal of the American College of Nutrition, 21, 166-173. http://dx.doi.org/10.1080/07315724.2002.10719261

[13] Einspanier, R., Klotz, A., Kraft, J., Aulrich, K., Poser, R., Schwagele, F., Jahreis, G. and Flachowsky, G. (2001) The fate of forage plant DNA in farm animals: A collaborative case-study investigating cattle and chicken fed recombinant plant material. European Food Research and Technology, 212, 129-134. http://dx.doi.org/10.1007/s002170000248

[14] Nowa, K.W. (2007) New perspectives for use of native and engineered recombinants foods and proteins untreat of food allergy. Immunology and Allergy Clinics of North America, 27, 105-127. http://dx.doi.org/10.1016/j.iac.2006.11.006

[15] Herrera, E.L. and Simpson, J. (1995) Genetically engineered resistance to bacterial and fungal pathogens. World Journal of Microbiology \& Biotechnology, 11, 383-392. http://dx.doi.org/10.1007/BF00364613

[16] ILSI (1996) Allergy and Immunology Institute and International Food Biotechnology Council. Allergenicity of food produced by genetic modification. CRC Press, Boca Raton.

[17] ILSI (2004) Comprehensive reviews in food science and food safety. Food Science \& Technology, 3, 44-49.

[18] Wolfenbarger, L.L. and Phifer, P.R. (2000) The ecological risks and benefits of genetically engineered plants. Science, 290, 2088-2093. http://dx.doi.org/10.1126/science.290.5499.2088

[19] American Association of Cereal Chemists (2000) Approved methods of the AACC.

[20] Association of Official Analytical Chemists (1999) Official methods of analysis vol II.

[21] Dewanto V., Wu, X. and Liu, R.H. (2002) Processed sweet corn has higher antioxidant activity. Journal of Agricultural and Food Chemistry, 50, 4959-4964. http://dx.doi.org/10.1021/jf0255937

[22] Kuiper, H.A., Kleter, G.A., Noteborn, H.P., Kok, E.J. (2001) Assessment of the food safety issues related to genetically modified foods. Plant Journal, 27, 503-528. http://dx.doi.org/10.1046/j.1365-313X.2001.01119.x

[23] Kanny, G., Monret, D., Flabbee, J., Beaudouin, E., Morisset, M. and Thevenin, F. (2001) Population study of food allergy in France. Journal of Allergy and Clinical Immunology, 108, 133-140. http://dx.doi.org/10.1067/mai.2001.116427

[24] Cesaretto, L., Vascotto C. and Calligaris, S. (2004) The importance of redox state in liver damage. Annals of $\mathrm{He}$ - 
patology, 3, 86-93.

[25] Lipton, C.R., Dautlick, J.X., Grothaus, G.D., Hunst, P.L., Magin, K.M., Mihaliak, C.A., Rubio, F.M. and Stave, J.W. (2000) Guidelines for the validation and use of immunoassays for determination of introduced proteins in biotechnology enhanced crops and derived food ingredients. Food and Agricultural Immunology, 12, 153-164. http://dx.doi.org/10.1080/095401000404094

[26] Cockburn, A. (2002) Assuring the safety of genetically modified foods. The importance of an holistic integrative approach. Journal of Biotechnology, 98, 79-106. http://dx.doi.org/10.1016/S0168-1656(02)00088-3

[27] Zolla, L., Rinalducci, S., Antonioli, P. and Righetti, P.G. (2008) Proteomics as a complementary tool for identi- fying unintended side effects occurring in transgenic maize seeds as a result of genetic modifications. Journal of Proteome Research, 7, 1850-1861. http://dx.doi.org/10.1021/pr0705082

[28] Ortiz-García, S., Ezcurra, B., Schoel, F, Acevedo, J. Soberón and Snow, A. (2006) Transgenic maize in Mexico, BioScience, 56, 709-803. http://dx.doi.org/10.1641/0006-3568(2006)56[709:TMIM 12.0.CO;2

[29] Williams, W.P., Gary, C., Buckley, P.M. and Daves, A.A. (2002) Aflatoxin accumulation in conventional and transgenic corn hybrid infested with southern corn borer. $J$. Agric. Urban Entomology, 19, 227-236. 